\title{
Co-Integration Tests and the Long-Run Purchasing Power Parity: A Case Study of India and Pakistan Currencies
}

\author{
Anwar Al-Gasaymeh¹, Gouher Ahmed ${ }^{2}$, Tariq Mehmood'2, Haitham M. Alzoubi2 \\ ${ }^{1}$ Applied Science Private University, Amman, Jordan \\ ${ }^{2}$ Skyline University College, Sharjah, UAE \\ Email: Gasaymeh@yahoo.com, Gouher@usa.net, tariq.mehmood@skylineuniversity.ac.ae, Haitham_zubi@yahoo.com
}

How to cite this paper: Al-Gasaymeh, A., Ahmed, G., Mehmood, T. and Alzoubi, H.M. (2019) Co-Integration Tests and the Long-Run Purchasing Power Parity: A Case Study of India and Pakistan Currencies. Theoretical Economics Letters, 9, 570-583. https://doi.org/10.4236/tel.2019.94040

Received: October 15, 2018

Accepted: March 23, 2019

Published: March 26, 2019

Copyright () 2019 by author(s) and Scientific Research Publishing Inc. This work is licensed under the Creative Commons Attribution International License (CC BY 4.0).

http://creativecommons.org/licenses/by/4.0/

\begin{abstract}
This is a study of the application of the purchasing power parity propositions to the interesting cases of India \& Pakistan through the Co-integration method. The results of the Co-integrations of both the nations demonstrate that the exchange rates are more in tandem with price movements supporting PPP theorem. This is interesting given the near-and-far off relationship between India and Pakistan owing to historical and contemporary factors which does not hold an irrational exchange rate. It is good for the two important developing nations to expand their economic and trade relationship which is a win-win situation for both countries. The study also points to the need of the two countries, with extensive poverty still in spite of their nearly seven decades' history of their development, to better manage their economies and currencies, the latter from fall and fall, which is dimming the international standing of their currencies. The study is a modest contribution to the literature on the Purchasing Power Parity theory with reference to the "special" cases of India and Pakistan.
\end{abstract}

\section{Keywords}

Purchasing Power Parity, Johansen Integration, India, Pakistan

\section{Introduction}

It is a matter of interest for both the learned and the way to know how foreign exchange rate determined, which, among others, determine, what one has to pay for imports and get from exports. It is an interesting matter to investigate in respect of any currencies. 
Indian sub-continent states of India and Pakistan appear to make good case studies of the problem, being so proximate each other, but with much difference in their exchange rate in terms of the USD. What explains this interesting question to be investigated.

The significance of the topic lies as India and Pakistan appear to treat each other as economically "exclusive" and quite independent of each other. Still, the rate of exchange of their currencies. Rupee may be related to their, relative "purchasing power", money being a medium of purchasing goods and services. So, does the more than 100-year-old but still, held greatly valid purchasing power parity theory PPP or 3-P theory hold valid in the mutually keeping a loaf, India and Pakistan with not much bilateral trade between then, on the basis of their price and exchange rate movements over time.

The study is a modest but theoretical and empirical contribution forming exchange rate determination with reference to foreign trade "received" cases of India and Pakistan.

Briefly, the study, first, draws a sketch of India-Pakistan economies and then the research process is explained in terms of data, statistical tools, etc. In the third stage, the results of the statistical exercises are put forth. Fourthly, the results are discussed. And, in the last the conclusions are drawn and their policy implications are driven home.

\subsection{India and Pakistan Economies}

India and Pakistan are the two neighboring Asian nations, between which there is a great deal of economic similarity, the two forming one under the colonial British Rule, until the bifurcation of the country in 1947 into India and Pakistan and their exchange rate. This paper addresses the long run PPP of India and Pakistan currencies and their exchange rate. There is a need for a good deal of comparative studies of India and Pakistan economies, but such studies appear, to be few and far between. It is needless to say, that the "value" of currencies, is a good reflection of the relative strength of their economies and the purchasing power (pp) of their currencies determine their rate of exchange or foreign exchange rate, say, if two currencies, Rs\&\$, are of equal by or purchasing power (PPP), then the rate of exchange of the two currencies is Rs\&\$, Rs $1=\$ 1$. Though this is a very simplistic explanation, it is being held all over.

As can be seen from the (Table 1), India and Pakistan both are lower middle income group (MIG) of countries with a Per Capita Income $>\$ 1000$ and $<\$ 2000$. The two are poverty ridden to the extent of over 20 per cent of the respective populations of 1.316 billion and 199.10 million. India is a \$ 2597 billion economy and Pakistan is a $\$ 304.9$ billion economy. Significantly, India has an edge in terms of all parameters except the ease of doing business, where it takes 34days while only 19 days in Pakistan. The two nations' PPP-PCI is $\$ 5630$ for India and $\$ 5090$ for Pakistan [1] [2]. Thus, Pakistan needs to improve its socio-economic parameters in relation to India. With its within 19 days business permissions, as against India's 34 days, Pakistan offers a better business environment than India. 
Table 1. India \& Pakistan major development \& economic indicators.

\begin{tabular}{lcc}
\hline \multicolumn{1}{c}{ Indicators } & India & Pakistan \\
\hline Income Level & Lower Middle Income & Lower Middle Income \\
GDP at Market Prices (Current US\$) (2017) & 2597.4 billion & $\$ 304.9$ billion \\
GNI Per Capita, Atlas Method, (Current USD) & $\$ 1670$ & $\$ 1500$ \\
Population (Total) (2017) & 1.316 billion & 199.10 million \\
Poverty head count ratio at national poverty lines & 21.9 (year 2016) & $29.5 \%$ (year 2016) \\
GNI Per Capita PPP (Current International \$) & $\$ 5630$ & $\$ 5090$ \\
Mortality Rate, under -5 (per 1000) & 49.8 & 83.3 \\
Inflation, GDP, deflator (annual \%) & $3.0 \%$ & $6.9 \%$ \\
Internet users per 100 people (2016) & 29.5 & 15.5 \\
Merchandise trade (\% of GDP) & $38 \%$ & $29.7 \%$ \\
Time required to start a business (days) & 34 days & 19 days \\
Exports of Goods and services (\% of GDP) & 23.2 & $12.3 \%$ \\
Imports of Goods and services (\% of GDP) & 25.5 & $18.7 \%$ \\
Surface area (sq. km) & $3,287,260.0$ & 796,100 \\
Life Expectancy & 68 (year 2013) & 66 years \\
Co2 emissions (metric tons per capita) (2011) & 1.7 & 0.9 \\
\hline
\end{tabular}

Source: World Bank (2016, 2017, 2018), The World Bank Group; ADB Basic Statistics (2018).

India and Pakistan belong to the South Asia region, made up of India, Pakistan, Bangladesh, Nepal, Bhutan, Afghanistan, Sri Lanka, which have made themselves into a regional group of SAARC (1982), of which India appears to be a high growing nation with a growth rate of $7.3 \%$ while Pakistan's growth rate is a modest 5.5\% (2015). This is in spite of the global financial crisis of 2008 and the Great Recession that followed it of 2008 [3] [4] [5] [6].

The prospects of growth in South Asia, India and Pakistan are improving, following higher investments, infrastructure development, FDI flows etc. which will have bearing upon trade prospects by means of availability of more goods and services. Pakistan is closely allied with China, which is helping the country in respect of big infrastructure projects with China, Pakistan Economic Corridor involving $\$ 40$ billion investment, with bright prospects for Pakistan-China trade. It is significant that China, which has emerged as a global trading power, is also a major trading partner of India, India-Pakistan appear as very distant trade partners.

On the whole, the transformation of India and Pakistan economies, in the last so many years, has been from low income countries to lower middle income (LMI) ones. And, under the impact of globalization, in the $21^{\text {st }}$ century, the efforts on economic development and higher growth rate are found enhanced.

\subsection{Economic-Growth, Exchange Rates and Foreign Trade}

The attempts of both India and Pakistan is to attain higher per capita income 
from their present relatively low levels, through economic growth over a long period of time of a generation or two, say, like China, through higher rate of economic growth. The latest growth record of the two countries is presented in Table-2, double digit growth. The experience of China held to be a means to overcome under-development and poverty, but the two countries are far from this goal Pakistan more so. In short-term, India and Pakistan should aim $8 \%$ and $6 \%$ growth rates, respectively, for, among other things, for higher values and better purchasing power of their currencies, which are found to be declining against the Dollar (\$) value or foreign exchange rate.

The Ratio of exchange of Rupee per Dollar is 1:70, and that of Pakistan is 1:140, and that of India-Pakistan 1:2, which may be reflective of the purchasing parity or power of the two currencies. The 3P or purchasing power parity (PPP) is that the ratio of exchange of currencies is on par with their purchasing power. In the case of India and Pakistan, Pakistan Rupee is of lower purchasing power vis-à-vis Indian Rupee, response of higher rate of inflation and large trade-gap. In Table 1, India-Pakistan respective rates of Inflation are $3 \%$ and $6 \%-7 \%$ and the trade gaps $2 \%-3 \%$ and $6.4 \%$ of GDP. Whether the long-term exchange and $3 \mathrm{Ps}$ ratios of the two nation converge. This is the problem under investigation in this modest but significant piece of study concerning two South Asian neighbors, economically distant. In terms of Table 2, India-Pakistan trade is interesting.

Both India and Pakistan have trade imbalances, the rate of imports growth exceeding that of exports, and trade growth is mainly driven by imports. India however is on a string growth. The result a falling foreign exchange rate of the two countries. However, in the adverse situation, the two countries appear reluctant to have any significance bilateral trade. Pakistan has no data on its exports to India. India has a surplus its Pakistan trade with (X-M) but their values are $(\mathrm{M}>\$ 0.5$ billion $)$ and $(\mathrm{Xs}=\$ 2$ billion $)$ maximum so far.

\section{The PPP Theory and Literature}

"The PPP theory says that the rate of exchange between two currencies is equal to their respective purchasing power parity say $\mathrm{f} 1=\$ 2$, meaning that what $\mathrm{f} 1$ buys in England is equal to what the $\$ 2$ buy in the USA" (Penguin Economic Dictionary, 1983, p. 337). The theory owes its origin to Mercantilism of the $17^{\text {th }}$ Century, of more exports and least imports. It was given a scientific form by Gustav Cassel of Sweden (1866-1945), in 1917, since when it has proved to be an enduring one (Penguin, 1983). There are "Stronger" and "Weaker" versions of it,

Table 2. GDP growth rate: India and Pakistan (\% Year).

\begin{tabular}{cccccc}
\hline Country & $\mathbf{2 0 1 5}$ & $\mathbf{2 0 1 6}$ & $\mathbf{2 0 1 7}$ & $\mathbf{2 0 1 8 f}$ & $\mathbf{2 0 1 9 f}$ \\
\hline India & 8.2 & 7.1 & 6.6 & 7.3 & 7.6 \\
Pakistan & 4.1 & 4.5 & 5.3 & 5.6 & 5.1 \\
\hline
\end{tabular}

Source: Asian Development Outlook (ADO) 2018. 
of 1:1 and not 1:1 price and exchange relationship [7] [8]. There are studies empirically testing the $3 \mathrm{P}$ proposition of price and exchange rate equality $(P=E)$ [9] [10] [11] [12], which on the whole hold the PPP's proposition.

$$
S=P / P^{*}
$$

where $S$ is the nominal exchange rate measured in units of domestic currency per unit of foreign currency, $P$ is the domestic price level and $P^{*}$ is the foreign price level. The relative PPP hypothesis, on the other hand, states that the exchange rate should be proportionate to the ratio of the price level and does not compare domestic and foreign levels of purchasing power, but rather focuses on changes in this purchasing power. Relative purchasing power parity theory, therefore, states that the inflation rate differentials between two countries are offset through inverse changes in the nominal exchange rate so that the purchasing power ratio between the two remains constant [13].

$$
S=k\left(P / P^{*}\right)
$$

where $k$ is a constant parameter, since information on national price levels normally is available in the form of price indices rather than absolute price levels, absolute PPP may be difficult to test empirically.

The PPP theory has been tested for several countries using various statistical methods, over different lengths of time. Despite the extensive research on PPP, there are only a few analyses for the Middle East countries [14] [15] [16], upholding the theory for the high-profile Middle East nations.

Al-Gasaymeh and Kasem [9] has tested two forms of purchasing power parity (PPP), specifically the strong form of PPP and the weak form of PPP between Jordan and its major trading partners namely, Japan, United Kingdom, Turkey, and United State, based on data covering the period of 2000M1-2012M12. Their results of cointegration tests show that there exists a cointegrating relationship for all the countries between exchange rate, domestic and foreign price levels.

\section{The Role of Country Characteristics on Purchasing Power Parity}

The distinction is to investigate whether trade, inflation and geographical (distance) contribute towards the validity of purchasing power parity in terms of trade, inflation and geographical (distance), to have a bearing on the theory. Therefore, also for countries with similar or resembling characteristics. India and Pakistan in this respect are a good case study of the problem. The study [10] examines the validity of Purchasing Power Parity and investigates the market integration using Unit root tests, Johansen co-integration test, and a vector error correction model were employed to test data covering the period 2005Q1-2012Q4 between Jordan and its major trading partners. The results provide evidence that the Purchasing Power Parity model holds in the long run investigation. Al-Gasaymeh [11] investigates, the role of country characteristics on Purchasing Power Parity for countries classified into three groups of trade agreements (FTA), high inflation and others, all standing by the theory. Paper [14] examines the va- 
lidity of purchasing power parity between a group of countries based on macroeconomics variables namely, high/low income and the highest GDP per capita over the period 2005Q1-2015Q4. The results of common unit root test LLC found evidence in favor of the validity of PPP. But the results of Im, Pesaran and Shin, ADF-Fisher and PP-Fisher unit root tests results failed to find evidence in the favor of validity of PPP for high/low income and GDP. So, the PPP theory is very live subject of empirical investigation.

Khan and Ahmad [15] work tests purchasing power parity as a long-run equilibrium condition by investigating the short run behavior of exchange rate and relative prices for four Asian countries by using cointegration approach, for the period 1976-2001 (25 years). They present the empirical evidence that cointegrated relationship does not exist in the sampled data. The results of the study are not supportive of the purchasing power parity proposition in most of the cases. Drine \& Rault [16] apply panel cointegration techniques to test the PPP for different panels of countries, such as the OECD, and countries in Africa, Asia, Middle East and North Africa (MENA), Latin America and Central and Eastern European. They reported favorable evidence of PPP in the OECD panel while weak PPP in MENA panel. For the remaining panels, their study shows that PPP does not seem to characterize the long-run behavior of the real exchange rates.

PPP empirical studies on Asian countries have found mixed results. [17] [18] [19] and [20] found evidence to support long-run PPP for Asian economies. However, [21] found mixed evidence of PPP from thirteen Asia Pacific economies. On the other hand, the results of [22] [23] [24] [25], and [26] for the G-6 and OECD countries, [27] for the industrial countries, [28] [29] for the OECD countries, [10] for the OECD, [30] for the G-10 countries, and, [31] for 17 developed countries. On the other hand, some studies have also shown that the real exchange rate is non-stationary, as done by [32] for the OECD countries, [33] for 65 developing countries, and [34] for eight Pacific countries and 15 developed countries, and so on. It is found that India and Pakistan are an untested field for PPP investigation. They make an interesting case study for PPP testing. It is important for them to know whether PPP holds for them for meaningful economic and trade relations. Hence, this study undertaking.

\section{Data and Methodology}

The data collected from different sources mainly from World Bank group is of time series for economy, trade and price movements for the period (2004-2014) (Appendix) enough period for a relationship to examine the time series properties. The unit root test of ADF test is used to examine the stationarity of the data. The unit root tests were first implement on level, and then on first difference of the data. If the series are of first order, then we may proceed to test the existence of the long-run relationship among these variables using Johansen cointegration test. If the maximum Eigen statistic and trace statistic greater than 5\% critical value, then we rejected the null hypothesis. By using Econometric Views-E 
Views software used and the following discussion outlines the basic features of ADF unit root tests. Consider a simple AR (1) process:

$$
y_{t}=p y_{t-1}+x_{t}^{\prime} \delta+\varepsilon_{t}
$$

where $x_{t}$ are optional exogenous repressors' which may consist of constant, or a constant and trend, $p$ and $\delta$ are parameters to be estimated, and the $\varepsilon_{t}$ are assumed to be white noise. If $[p] \geq 1, y$ is a nonstationary series and the variance of $y$ increases with time and approaches infinity, if $[p]<1, y$ is a (trend-) stationary series, thus, the hypothesis of (trend-) stationarity can be evaluated by testing whether the absolute value of $p$ is strictly less than one.

The unit root tests generally test the null hypothesis $H_{0}: p=1$ against the one-sided alternative $H_{1}: p<1$.

The test of weak PPP consists in testing the existence of a cointegration relationship between the nominal exchange rate and the price ratio. Let,

$$
E=k\left(P / P^{*}\right)
$$

where $k$ is a constant parameter

Rewrite Equation (2) in log form

$$
\log e_{t}=\beta_{1} \log p_{t}-\beta_{2} \log p^{*}
$$

Estimation cointegration regression

$$
\begin{aligned}
& \log e_{t}=c+\beta_{1} \log p_{t}-\beta_{2} \log p^{*}+\varepsilon_{t} \\
& \log e_{t}-c-\beta_{1} \log p_{t}+\beta_{2} \log p_{t}^{*}=\varepsilon_{t}
\end{aligned}
$$

where $e_{t}, p$ and $p^{*}$ are the exchange rate, the domestic price, and the foreign price respectively, $t$ denoted for time subscript and $c$ is constant, $\varepsilon_{t}$ is the error term, if $\varepsilon_{t}$ is a stationary process with zero mean then PPP holds in the long run. However, if $\varepsilon_{t}$ is non stationary implying that deviation from PPP are cumulative and not ultimately self-reversing, then PPP fails in the long run.

Let $X_{t}=\left(e_{t}, p_{t}, p_{t}^{*}\right)$. If all components in $X_{t}$ are integrated of order $1,(I(1)$, if the cointegration vector satisfies the restriction of proportionality, i.e., $\alpha=(1,-1,1)$. Hence, testing the cointegration among $e_{t}, p$ and $p^{*}$ examining the proportional restriction of the cointegration vector are ways of testing the validity of PPP.

Then, the test of cointegration between the nominal exchange rate and the national price levels by estimating the following regression:

$$
\log e_{t}-c-\beta_{1} \log p_{t}+\beta_{2} \log p_{t}^{*}=\varepsilon_{t}
$$

where $e$ is the nominal exchange rate, $P, P^{*}$ the domestic price, and the foreign price respectively and $c=$ constant, $\beta_{1}, \beta_{2}=$ coefficient, $\varepsilon_{t}=$ error term.

For strong PPP to be valid $\beta_{1}$ should be positive and equal to one, $\beta_{2}$ should be negative and equal to 1 in order for PPP to hold. For relative PPP, $\beta_{1}$ and $\beta_{2}$ do not need to be equal to 1 .

\section{Cointegration Test}

After a careful compilation of data, cointegration procedure, developed by Joh- 
hansen, (1988) and Johansen-Juselius, (1990) is employed to examine long-term relationship between the different models within economics, as proposed in the coming parts. Cointegration refers to the possibility that non-stationary variables can be a linear combination that is stationary. From a statistical perspective, a long-term relationship means that the balance variables move together in time, so that any short-term deviations from long-term trend will be corrected. These series are said to be cointegrated and therefore, a common root stochastic trend. Johansen-Juselius, procedure again, in the $n$-variable first order given by VAR.

$$
\Delta X_{t}=A_{1} X_{t-1}+\varepsilon_{t}
$$

By subtracting $X_{t-1}$ from each side of the equation, equation (9) can be rewritten as:

$$
\begin{aligned}
\Delta X_{t} & =A_{1} X_{t-1}+X_{t-1}+\varepsilon_{t} \\
& =\left(A_{1}-I\right) X_{t-1}+\varepsilon_{t} \\
& =\pi X_{t-1}+\varepsilon_{t}
\end{aligned}
$$

where $X_{t-1}$ and $\varepsilon_{t}$ are $(n \times 1)$ vectors; $A$ is an $(n \times n)$ matrix of parameters; $I$ is an $(n \times n)$ identity matrix; and $\pi$ is defined as $\left(A_{1}-I\right)$. The rank of $\pi$ equals to the number of cointegration vectors, also, the model in equation (10) can be generalized to allow for a higher-order autoregressive process,

$$
\Delta X_{t}=\sum_{i=1}^{m-1} \pi_{i} \Delta X_{t-i}+\pi i X_{t-m}+\varepsilon_{\varepsilon t}
$$

The most important function is still the grade as equal to the number of independent cointegration vectors. As we know that the rank of a matrix is equal to the number of its characteristics which are different from zero, so the number of individual cointegration vectors in this model may be determined by checking whether the significance of the characteristic roots $\pi$. The test for the number of cointegration vectors can be accomplished with the help of two like hood ratios (LR) test on the track of statistics and maximum eigenvalue statistics as shown below:

Trace Test:

$$
L_{\text {trace }(r)}=-T \sum L_{n}\left(1-\lambda_{i}\right)
$$

Maximum eigenvalue test:

$$
L_{\max (r, r+1)}=-T L_{n}\left(1-\lambda_{r+1}\right)
$$

where $\lambda_{I}$ the estimated eigenvalues and $T$ is the number of valid observations, the null hypothesis of traces of statistical tests that the number of individual cointegration vector is smaller than or equal to $r$ against a general alternative which gives the result of not more than rcointegrating vectors the last $\lambda \max$ statistical tests the null hypothesis that there is vector $r$ cointegrating against the alternative of $r+1$ cointegrating vectors. In general $\lambda$ max statistics is more 
preferable, because it represents the result of exactly $r$ cointegrating vectors. Critical values for both tests are in a table (Osterwald-Lenum, 1992).

\section{Results and Discussion}

The result of ADF test in Table 3 shows that the null hypothesis of unit root for both countries cannot be rejected at $1 \%$ significant level when all the variables are in the level but can be rejected when they are tested at first difference, which means all the variables are stationary at first difference. However, the null hypothesis of stationary cannot be rejected when all variables are tested in their first differences. Thus, we concluded that all the series are $I(1)$ process.

All the series are $I(1)$ process; the cointegration test can be implement and proceeded to examine the long-run relationship among the variables. Table 4 reports the results for the Johansen cointegration test which showed that there exists a cointegrating relationship between exchange rate, and price levels for Pakistan and India. The existence of a long run relationship between the exchange rates of Pakistan and India, CPI Pakistan and CPI India supports the theory of PPP, over a period of time.

The result holds that any artificial trade barriers do not hold any good. They come at an unavoidable "cost" to the economies and the people of the two countries. The result hold that Indian and Pakistan trade is a "win-win" situation for both the nations.

The result comes as a pleasant surprise for good and fair economic relations between India and Pakistan, which may open a new chapter of mutual friendship and amity between the two countries.

Table 3. The ADF unit root test.

\begin{tabular}{ccccc}
\hline \multirow{2}{*}{ Variable } & \multicolumn{2}{c}{ At Level } & \multicolumn{2}{c}{ First Difference } \\
\cline { 2 - 5 } & Constant & Trend & Constant & Trend \\
\hline ER Pakistan-India & $-3.53(2)$ & $-3.49(4)$ & $-5.34(2)^{* * *}$ & $-3.41(2)^{* * *}$ \\
CPI Pakistan & $-2.61(0)$ & $-2.80(0)$ & $-6.45(0)^{* * *}$ & $-6.76(0)^{* * *}$ \\
CPI India & $-3.29(4)$ & $-5.25(1)$ & $-3.21(3)^{* * *}$ & $-10.32(0)^{* * *}$ \\
\hline
\end{tabular}

Notes: Figures are the $\mathrm{t}$-statistics for testing the null hypothesis that the series is nonstationary. ${ }^{* *}$ and ${ }^{* *}$ denotes significance at $1 \%$ and $5 \%$ levels. Figures in parenthesis are lag length.

Table 4. The Johansen-Juselius cointegration tests.

\begin{tabular}{cccccc}
\hline Null Hypotheses & Eigenvalue & Trace & Critical Value (1\%) & Max-Eigen & Critical Value (5\%) \\
\hline \multicolumn{5}{c}{ Pakistan-India } \\
\hline$(\mathrm{r}=0)$ & 0.342 & $52.86^{* * *}$ & 45.65 & $25.65^{* * *}$ & 22.52 \\
$(\mathrm{r} \leq 1)$ & 0.076 & 5.56 & 30.04 & 5.54 & 15.53 \\
$(\mathrm{r} \leq 2)$ & 0.005 & 0.65 & 4.76 & 0.532 & 5.62 \\
\hline
\end{tabular}

Notes: $r$ indicates the number of cointegrating vectors. ${ }^{* * *}$ and ${ }^{* *}$ denote significance at $1 \%$ and $5 \%$ levels. 


\section{Robustness of Research}

This is a concerned piece of technical research, sound in theory, data, length of time, without any pre-mediated propositions and biases, in the interest of trade and other economic relations of India and Pakistan which are bound by history, geography, traditions and culture, currencies and trade. For so aligned countries, the results of the study of economic and trade interdependence cannot be called "freak". The research study is technically sound and of a high order. The researchers have the interests of both the nations in mind for the wellness of their people.

\section{Conclusions and Recommendation}

India and Pakistan are strange cases of countries which are geographically near, but which hold them apart economically swing to the bitterness of partition and the mass exodus of people and sad memories, and still on-going territorial disputes and armed conflicts over them.

But the economies of the trade bind them together, which is amply proved by this model note of research. The Note opens a new era of good trade and economic relations, according to the Results hold a brighter economic prospect for the two countries.

The results of cointegration tests show that there exists a co-integrating relationship between exchange rate, domestic and foreign price levels, lending support to the validity of PPP. The findings of PPP, hold valid for Pakistan and India implies that the Pakistan economy is integrated with the economy of India.

The important policy implication is a good case for a cross-border agreement for trade and investment between the two countries. To promote trade benefit for the two economies, there is a need for removal of trade barriers, and promoting economic trade and socio-cultural and people relationship on "give-and-like" basis, and mutual trust and friendship.

The new and high and fair minded United Arab Emirates (UAE), wherein people of different faiths and nationalities fully feel at home and safe, is a model for India-Pakistan relationship [35].

With the goods and services markets appearing quite integrated liberalization of financial markets may take place. If we envision this process of integration continuing, then there will be the prospect of multi-dimensional cooperation between the two nations.

As a way forward in India-Pakistan bilateral trade, in place of bilateral bitterness and born enmity, Pakistan should agree for MFN status for India, which India had conferred on Pakistan way back in 2006.

Also, the study indicates the need of the two countries to better manage their economies and guard their currencies from continuous depreciation which is not good for their international image "Fair" economic co-operation rather than conflict is bound to raise the global standing of the economies of the two countries and make them look as somewhat equitable societies, same mass poverty. 
Not the least, PPP which has its roots in the medieval mercantilist school of trade, is still found valid, as the nations are interdependent. The overall lesson and prescription of the study is for the two-warring neighborhood is hold the price-line, look after your currency values, promote thrift investment and growth and overall prosperity and environmental well-being.

\section{Conflicts of Interest}

The authors declare no conflicts of interest regarding the publication of this paper.

\section{References}

[1] World Bank (2015) Global Economic Prospects: The Global Economy in Transition. World Bank, Washington DC.

[2] World Bank (2016) Global Economic Prospects: Spillovers amid Weak Growth. World Bank Group, Washington DC.

[3] Ahmed, G. (2013) Recessionary Global Business Environment. Global Journal of Research in Management, 3, 1-14.

[4] Ahmed, G., Agnihotri, M., Abdulsalam, M. and Mehmood, T. (2016) Honesty is the Best Business Policy: The Ethics of International Business. Journal of Global Business Management, 12, 101-108.

[5] Ahmed, G. (2017) A Quarter Century of Economic Reforms of India (1991-2016). Theoretical Economics Letters, 7, 1102-1107. https://doi.org/10.4236/tel.2017.75074

[6] Ahmed, G. and Rafiuddin, A. (2018) Cultural Dimensions of Economic Development: A Case of UAE. Theoretical Economics Letters, 8, 2479-2496.

https://doi.org/10.4236/tel.2018.811160

[7] Cheung, Y.-W. and Lai, K.-S. (1993) A Fractional Cointegration Analysis of Purchasing Power Parity. Journal of Business and Economic Statistics, 11, 103-112.

[8] Taylor, M.P. (1988) An Empirical Examination of Long-Run Purchasing Power Parity Using Cointegration Techniques. Applied Economics, 20, 1369-1381. https://doi.org/10.1080/00036848800000107

[9] Al-Gasaymeh, A. and Kasem, J. (2015) Strong and Weak Form of Purchasing Power Parity: The Case of Jordan and Its Major Trading Partners. Journal of International Business and Economics, 3, 93-108. https://doi.org/10.15640/jibe.v3n1a11

[10] Al-Gasaymeh, A. and Kasem, J. (2016) Long-Run Purchasing Power Parity and Exchange Rates: Evidence from the Middle East. The International Journal of Business and Finance Research, 10, 41-53.

[11] Al-Gasaymeh, A., Kasem, J. and Alshurideh, M. (2015) Real Exchange Rate and Purchasing Power Parity Hypothesis: Evidence from ADF Unit Root Test. International Research Journal of Finance and Economics, 14, 450-2887.

[12] Husted, S. and MacDonald, R. (1998) Monetary-Based Models of the Exchange Rate: A Panel Perspective. Journal of International Financial Markets, Institutions and Money, 8, 1-19. https://doi.org/10.1016/S1042-4431(98)00021-3

[13] Suranovic, S. (1999) Introduction to Purchasing Power Parity (PPP). Chapter 30. In: Suranovic, S., Ed., International Finance: Theory and Policy, The Saylor Foundation, Washington DC.

[14] Al-Gasaymeh, A. (2016) Macroeconomic Variables and Validity of PPP Theorem: 
An Examination of Panel Unit Root Method. Global Review of Accounting and Finance, 7, 120-128. https://doi.org/10.21102/graf.2016.03.71.09

[15] Khan, F. and Ahmad, E. (2015) Test of Purchasing Power Parity Based on Cointegration Technique the Asian Evidence. Pakistan Economic and Social Review, 2, 167-183.

[16] Drine, I. and Rault, C. (2008) Purchasing Power Parity for Developing and Developed Countries: What Can We Learn from Non-Stationary Panel Data Models? Journal of Economic Surveys, 22, 752-773. https://doi.org/10.1111/j.1467-6419.2007.00548.x

[17] Phylaktis, K. and Kassimatis, Y. (1994) Does the Real Exchange Rate Follow A Random Walk? The Pacific Basin Perspective. Journal of International Money and Finance, 13, 476-495. https://doi.org/10.1016/0261-5606(94)90051-5

[18] Salehizadeh, M. and Taylor, R. (1999) A Test of Purchasing Power Parity for Emerging Economies. Journal of International Financial Markets, Institutions and Money, 9, 183-193. https://doi.org/10.1016/S1042-4431(99)00006-2

[19] Wang, P. (2000) Testing PPP for Asian Economies during the Recent Floating Period. Applied Economics Letters, 7, 545-548. https://doi.org/10.1080/13504850050033355

[20] Azali, M., Habibullah, M.S. and Baharumshah, A.Z. (2001) Does PPP Hold between Asian and Japanese Economies? Evidence Using Panel Unit Root and Panel Cointegration. Japan and the World Economy, 13, 35-50. https://doi.org/10.1016/S0922-1425(00)00055-4

[21] Lee, Y. (1999) Purchasing Power Parity and Dynamic Error Correction Evidence from Asian Pacific Economies. International Review of Economies and Finance, 8, 199-212. https://doi.org/10.1016/S1059-0560(99)00015-5

[22] Cooper, J.C.B. (1994) Purchasing Power Parity: A Cointegration Analysis of the Australian, New Zealand and Singaporean Currencies, Applied Economics Letters, 1, 167-171. https://doi.org/10.1080/135048594357934

[23] Doganlar, M. (1999) Testing Long-Run Validity of Purchasing Power Parity for Asian Countries, Applied Economics Letters, 6, 147-151. https://doi.org/10.1080/135048599353519

[24] Holmes, M. (2001) New Evidence on Real Exchange Rate Stationarity and Purchasing Power Parity in Less Developed Countries. Journal of Macroeconomics, 23, 601-614. https://doi.org/10.1016/S0164-0704(01)00180-X

[25] Alba J.D. and Papell D.H. (2007) Purchasing Power Parity and Country Characteristics: Evidence from Panel Data Tests. Journal of Development Economics, 83, 240-251. https://doi.org/10.1016/j.jdeveco.2005.09.006

[26] Oh, K.Y. (1996) Purchasing Power Parity and the Unit Root Tests Using Panel Data. Journal of International Money and Finance, 15, 405-418. https://doi.org/10.1016/0261-5606(96)00012-5

[27] Papell, D. (1997) Searching for Stationarity: Purchasing Power Parity under the Current Float. Journal of International Economics, 43, 313-332. https://doi.org/10.1016/S0022-1996(96)01467-5

[28] Lothian, J. (1997) Multi-Country Evidence on the Behavior of Purchasing Power Parity under the Current Float. Journal of International Money and Finance, 16, 19-35. https://doi.org/10.1016/S0261-5606(96)00047-2

[29] Lothian, J.R. (1998) Some New Stylized Facts of Floating Exchange Rates. Journal of International Money and Finance, 17, 29-39. 
https://doi.org/10.1016/S0261-5606(97)00048-X

[30] Coakley, J. and Fuertes, A.M. (1997) New Panel Unit Root Tests of PPP. Economics Letters, 57, 17-22. https://doi.org/10.1016/S0165-1765(97)81874-5

[31] Koedijk, K.G., Schotman, P.C. and Dijk, M.A.V. (1998) The Re-Emergence of PPP in the1990s. Journal of International Money and Finance, 17, 51-61. https://doi.org/10.1016/S0261-5606(97)98051-7

[32] Canzoneri, M.B., Cumby, R.E. and Diba, B. (1999) Relative Labor Productivity and the Real Exchange Rate in the Long Run: Evidence for a Panel of OECD Countries. Journal of International Economics, 47, 245-266. https://doi.org/10.1016/S0022-1996(98)00021-X

[33] Alba, J.D. and Park, D. (2003) Purchasing Power Parity in Developing Countries: Multi-Period Evidence under the Current Float. World Development, 31, 2049-2060. https://doi.org/10.1016/j.worlddev.2003.06.008

[34] Wu, J. L. and Chen, S. L. (1999) Are Real Exchange Rates Stationary Based on Panel Unit-Root Tests? Evidence from Pacific Basin Countries. International Journal of Finance and Economics, 4, 243-252.

[35] Amponsah, C. and Ahmed, G. (2017) New Global Dimensions of Business Excellence. International Journal of Business Excellence, 13, 60-78.

https://doi.org/10.1504/IJBEX.2017.085794 


\section{Appendix}

Table A1. India and Pakistan exchange rates and foreign trade (2004-2014), (Value and \% Share).

\begin{tabular}{|c|c|c|c|c|c|c|c|c|c|c|c|}
\hline & 2004 & 2005 & 2006 & 2007 & 2008 & 2009 & 2010 & 2011 & 2012 & 2013 & 2014 \\
\hline $\begin{array}{l}\text { India Exchange Rate } \\
\text { per \$ US average }\end{array}$ & 45.3 & 44.1 & 45.3 & 41.3 & 43.5 & 48.4 & 45.7 & 46.7 & 53.4 & 58.6 & 61.0 \\
\hline $\begin{array}{l}\text { India External Trade-annual } \\
\text { change, percent -Exports }\end{array}$ & 27.9 & 21.6 & 25.3 & 14.7 & 28.2 & 2.7 & 35.1 & 27.1 & 12.5 & 15.8 & 0.2 \\
\hline $\begin{array}{l}\text { India External Trade-annual } \\
\text { change, percent -Imports }\end{array}$ & 39.5 & 31.8 & 27.3 & 20.4 & 35.8 & 3.5 & 22.7 & 37.1 & 14.1 & 3.1 & 0.0 \\
\hline India Exports to Pakistan & 521.05 & 689.23 & 1350.09 & 1950.53 & 1439.88 & 1573.32 & 2039.53 & 1541.56 & 2064.79 & 2274.26 & 1857.18 \\
\hline [Indias Total Exports) & $(83,535)$ & $(103,090)$ & $(126,414)$ & $(163,132)$ & $(185,295)$ & $(178,751)$ & $(249,815)$ & $(305,963)$ & $(300,400)$ & $(314,405)$ & $(310,338)$ \\
\hline $\begin{array}{l}\text { [\% of Indias Exports } \\
\text { to Pakistan] \$mln }\end{array}$ & {$[0.623]$} & {$[0.668]$} & {$[1.06]$} & [1.19] & {$[0.777]$} & {$[0.880]$} & {$[0.816]$} & {$[0.503]$} & {$[0.687]$} & {$[0.7234]$} & {$[0.5984]$} \\
\hline \multicolumn{12}{|l|}{ (Fiscal Year 2013-14) } \\
\hline India Imports from Pakistan & 94.97 & 179.56 & 323.62 & 287.97 & 370.17 & 275.94 & 332.51 & 397.66 & 541.87 & 426.88 & 497.31 \\
\hline (Total Indias Imports) & $(111,517)$ & $(149,165)$ & $(185,735)$ & $(251,654)$ & $(303,696)$ & $(288,372)$ & $(369,769)$ & $(489,319)$ & $(490,736)$ & $(450,199)$ & $(448,033)$ \\
\hline $\begin{array}{l}\text { [\% of Indias Imports } \\
\text { from Pakistan] \$mln }\end{array}$ & {$[0.085]$} & {$[0.120]$} & {$[0.174]$} & {$[0.114]$} & {$[0.121]$} & {$[0.095]$} & {$[0.089]$} & {$[0.081]$} & {$[0.110]$} & {$[0.094]$} & {$[0.111]$} \\
\hline \multicolumn{12}{|l|}{ (Fiscal Year 2013-14) } \\
\hline $\begin{array}{l}\text { Pakistan Exchange Rate, Local } \\
\text { Currency per US\$ (average) }\end{array}$ & 58.3 & 59.5 & 60.285 & 60.73 & 70.73 & 81.72 & 85.17 & 86.35 & 93.38 & 101.6 & 101.1 \\
\hline Pakistan External & & & & & & & & & & & \\
\hline $\begin{array}{l}\text { Trade-annual change, } \\
\text { percent-Exports }\end{array}$ & 11.9 & 17.3 & 15.4 & 4.7 & 19.5 & 13.2 & 16.7 & 31.1 & -1.0 & 11.6 & 8.7 \\
\hline $\begin{array}{l}\text { Pakistan External } \\
\text { Trade-annual change, } \\
\text { percent-Imports }\end{array}$ & 25.7 & 36.6 & 39.4 & 8.2 & 35.7 & 8.5 & 6.8 & 18.8 & 16.0 & 8.4 & 6.5 \\
\hline Pakistan Exports to India & $\mathrm{Na}$ & $\mathrm{Na}$ & $\mathrm{Na}$ & $\mathrm{Na}$ & $\mathrm{Na}$ & $\mathrm{Na}$ & $\mathrm{Na}$ & $\mathrm{Na}$ & $\mathrm{Na}$ & $\mathrm{Na}$ & $\mathrm{Na}$ \\
\hline Pakistan Imports from India & 634.0 & 731.7 & 927.2 & 1382.9 & 1905.6 & 1605.7 & 2513.6 & 28.5 .8 & 2037.8 & 1824.9 & 1341.6 \\
\hline
\end{tabular}

Asian Development Bank, Key Indicators of Asia \& Pacific 2015; Government of India, Ministry of Commerce \& Industry, Department of Commerce (2016) http://commerce.nic.in/ei 